\title{
A COMPARATIVE STUDY OF PRAGMATIC DIFFERENCES OF POLITENESS LANGUAGE IN ENGLISH AND CHINESE
}

\author{
Maftuna A. Boboraimova \\ Lecturer, National University Of Uzbekistan Named After Mirzo Ulug'bek \\ Odina M. Mukhamedova \\ Lecturer, National University Of Uzbekistan Named After Mirzo Ulugbek
}

\section{ABSTRACT}

English and Chinese have different polite language. The pragmatic differences in polite language between English and Chinese can lead to pragmatic obstacles and pragmatic failure. This article aims to compare the differences in the specific application of English and Chinese polite language, and analyze the cultural factors that cause these pragmatic differences, so as to help learners reduce and eliminate pragmatic barriers and pragmatic failures.

KEYWORDS: - English and Chinese polite language; pragmatic differences; cultural factors; each nation has its own polite language, which can reflect a nation's cultural background, customs, political history, etc.

\section{INTRODUCTION}

Language is the carrier of culture, and the different usage of polite language in different countries reflects different cultural phenomena.

China is known as the «state of etiquette». Chinese people also follow the principle of etiquette in their interactions with Westerners. However, the cultural conflicts and communication barriers caused by people from two different cultural backgrounds are even It is that communication failure is very common. «Pragmatic differences» refer to the polite cultural differences in pragmatics, that is, people with different cultural backgrounds have differences in the way of expressing polite language, which leads to pragmatic barriers and pragmatic failure.

\section{THE MAIN RESULTS AND FINDINGS}

This article aims to explore the specific manifestations of such pragmatic barriers and analyze the cultural factors that cause these 
CURRENT RESEARCH JOURNAL OF PHILOLOGICAL SCIENCES 2(12):

75-78, December 2021

DOI: https://doi.org/10.37547/philological-crjps-02-12-16

ISSN 2767-3758

(C)2021 Master Journals

Crossref do

gil Google

Accepted09th December, 2021 \& Published 14 ${ }^{\text {th }}$ December, 2021

pragmatic differences, so as to help learners reduce and eliminate pragmatic barriers and pragmatic failures. 2. Pragmatic differences in social language 1. Pragmatic differences between thank you and apology The most commonly used thank you in Westerners is Thankyou. It is not completely equivalent to the Chinese «thank you».

Westerners say Thank you much more often than Chinese say «thank you». Under normal circumstances, Chinese people seldom say «thank you» to their family members, such as husband and wife, mother and child. Among close friends, they often express gratitude in other more euphemistic terms, such as Having to use such a polite language will make the other person feel strange and uncomfortable, and widen the distance between each other.

Westerners talk about «Thank you» and say that to anyone. When others thank you'Thank you very much.' If Chinese people say «Never mind» or «It doesn't matter.» according to the virtue of humility, it would be very out of date. Because Never mind. Or It doesn't matter.-It's usually used to reply to the other party's apologies. Westerners usually say «»m glad you think SO.» or «You're welcome.»

The apology terms commonly used by Westerners include So Ting and Excuse me. So generally refers to apologizing to the other party after doing something wrong, and Excuse me is often similar to our Chinese meaning of «Excuse me».

Pragmatic differences between compliments and congratulations. Westerners never spare good words. They often put compliments to others on their lips. Therefore, we often see conversations between foreign teachers and Chinese students:

A: Your English is excellent. B: NO, my English is poor.

Westerners will inevitably feel unhappy about such denials. They find it difficult to understand the modesty of Chinese people, but hope that the other party can happily accept saying «Thank you» or «Really? I'm glad you think so.» The pragmatic difference of the banquet is a guest in a Chinese home. The host will set up a table of hearty meals, but what he says is: "Today's food is not good, please bear with me. .» or "There is no food today, it's just a casual meal.» Westerners will find it very difficult to understand, and they don't feel good about it. Why do you want to entertain me? When visiting a Westerner, they will say: «This is the most distinctive restaurant in our region.» or «This is my wife's specialty.

Chinese people like to persuade their friends to eat food constantly during the banquet, and even personally pick up dishes for them to show their hospitality. Westerners are very uncomfortable because they usually only say «He| p yourself.» when entertaining friends. (iß

Pragmatic differences in daily greetings Chinese people like to ask each other: «Have you eaten?» Translated to Westerners

Is it «Have you had meal?» or «Have you eaten?» They will not understand it, and even mistakenly think that you want to eat with him. The Chinese go to the airport to meet Western friends to visit and play. When the guests get off the plane, the Chinese will say: «Welcome, welcome, all the way

Thanks for your hard work. «Translated into English is «Welcome.»

You must be tired all the wa Westerners will be surprised to hear such greetings, they will reply Replied, «No, no. I'm nottired at a» The greetings that Westerners are used to in such occasions For, «You've had a long trip.» or «Did you have a good flight?»

5. Pragmatic Differences in Addressing Forms Chinese people are accustomed to calling older 
CURRENT RESEARCH JOURNAL OF PHILOLOGICAL SCIENCES 2(12):

75-78, December 2021

DOI: https://doi.org/10.37547/philological-crjps-02-12-16

ISSN 2767-3758

(C)2021 Master Journals

Crossref do

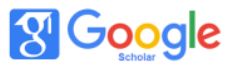

Accepted09th December, 2021 \& Published 14 ${ }^{\text {th }}$ December, 2021

people «Lao», such as «Lao Zhang», «Lao Li», etc., There is no disrespect or derogatory meaning of such a term. For some highly respected elders, we will also call them «a certain old man» or «a certain old man». This kind of watch

The title of respect is unacceptable to Westerners Accepted because in English we put 0| d, senior, elderly is extremely impolite to address the elderly. Cultural factors that cause pragmatic differences The differences in values Chinese people emphasize Collectivism (collectivism), while Westerners value individualism (individualism), so Chinese people often say, «My success is inseparable from the support of my leaders and the care of comrades over the years. This is the collective contribution.» «Westerners often find it difficult to understand such words, let alone understand the Chinese phrases such as «people are afraid of being famous, pigs are afraid of being strong», «shooting birds» and other sentences. In the eyes of Westerners, individual rights cannot be violated. From the perspective of language and culture, their «l» is always capitalized, and other people's names are not capitalized. This is the opposite of China's selfhumility and respect for others.

\section{Differences in ethics and morals}

Chinese people value the difference in hierarchy, and they pay attention to the order of elders and children. When they see the elders, they must use respect and respect, while Westerners pay attention to equality and less formality. Therefore, Chinese people have different ways of addressing and greeting different people, while Westerners can equally use «Hello» to express greetings, and they can also call their elders and teachers by their first names.

Differences in ways of thinking Chinese people like to visit friends, and the concept of time is not very strong, and they often don't mention it.

Make an appointment in advance or set a good time for the conversation, which is very random, and when you forget it when you talk about it

Between. Westerners have a strong sense of time and efficiency, and will not go to other people's homes to chat for no reason. If they want to occupy other people's time, they will also ask ${ }^{\circ}$ Coutail you first.

Spare me a few minutes?» (Can occupy you any time? ) Before leaving, the traditional Chinese report don't say «Sit down for a while», you walk slowly. «like

The direct translation is «Stay for more time.» and «Go slowly.» Westerners will be very confused, they usually say «Goodbye.» or'Thank you for coming.

\section{Conclusion}

In short, as a special and universal social and cultural phenomenon, polite language occupies an important position in social communication, especially in international communication. It is better to study the pragmatic differences of polite language in English and Chinese.

Help us understand the Western thinking style and cultural background, thereby reducing and avoiding pragmatic barriers caused by pragmatic differences, achieving the purpose of smooth communication and pleasant cooperation. At the same time, it is also more conducive to spreading Chinese culture to the world.

\section{REFERENCES}

1. He Zhaoxiong. The new summary of pragmatics [M] Shanghai: Shanghai Foreign 
CURRENT RESEARCH JOURNAL OF PHILOLOGICAL SCIENCES 2(12):

75-78, December 2021

DOI: https://doi.org/10.37547/philological-crjps-02-12-16

ISSN 2767-3758

(C)2021 Master Journals

Crossref doi) 81 Google

Accepted09th December, 2021 \& Published 14 ${ }^{\text {th }}$ December, 2021

Language Education Press, 2000.

2. Gu Yueguo. Polite. Pragmatics and culture [J]. Foreign Language Teaching and Research, 1992, (4):1 1.14.

3. Wang Junlan. A Comparative Analysis of the Cultural Characteristics of Politeness in Chinese and English[J], Journal of Northwest University for Nationalities, 2003 